\title{
Domain rearrangement of SRP protein Ffh upon binding 4.5S RNA and the SRP receptor FtsY
}

\author{
IWONA BUSKIEWICZ, ${ }^{1}$ ANDRIY KUBARENKO, ${ }^{2}$ FRANK PESKE, ${ }^{1}$ MARINA V. RODNINA, ${ }^{2}$ \\ and WOLFGANG WINTERMEYER ${ }^{1}$ \\ ${ }^{1}$ Institute of Molecular Biology and ${ }^{2}$ Institute of Physical Biochemistry, University of Witten/Herdecke, 58448 Witten, Germany
}

\begin{abstract}
The signal recognition particle (SRP) mediates membrane targeting of translating ribosomes displaying a signal-anchor sequence. In Escherichia coli, SRP consists of 4.5S RNA and a protein, Ffh, that recognizes the signal peptide emerging from the ribosome and the SRP receptor at the membrane, FtsY. In the present work, we studied the interactions between the NG and $M$ domains in Ffh and their rearrangements upon complex formation with 4.5S RNA and/or FtsY. In free Ffh, the NG and M domains are facing one another in an orientation that allows cross-linking between positions 231 in the $G$ domain and 377 in the $M$ domain. There are binding interactions between the two domains, as the isolated domains form a strong complex. The interdomain contacts are disrupted upon binding of Ffh to 4.5S RNA, consuming a part of the total binding energy of 4.5S RNAFfh association that is roughly equivalent to the free energy of domain binding to each other. In the SRP particle, the NG domain binds to 4.5S RNA in a region adjacent to the binding site of the $M$ domain. Ffh binding to Fts $Y$ also requires a reorientation of NG and $M$ domains. These results suggest that in free Ffh, the binding sites for 4.5S RNA and FtsY are occluded by strong domain-domain interactions which must be disrupted for the formation of SRP or the Ffh-FtsY complex.
\end{abstract}

Keywords: protein targeting, translation, protein export, bimane cross-linking, fluorescence resonance energy transfer

\section{INTRODUCTION}

The signal recognition particle (SRP) is a ribonucleoprotein that targets ribosomes translating secretory or inner-membrane proteins to the translocation pore located in the membrane of the endoplasmic reticulum in eukaryotes or the plasma membrane in prokaryotes (Keenan et al. 2001; Nagai et al. 2003; Doudna and Batey 2004). The SRP recognizes and binds to hydrophobic signal sequences as they emerge from ribosome nascent-chain complexes (RNC). The RNC-SRP complex is directed to the membrane by the interaction with the membrane-associated SRP receptor, and the RNC is transferred to the translocation pore through which the nascent protein passes during further elongation. In Escherichia coli, the SRP consists of $4.5 \mathrm{~S}$ RNA ( 114 nucleotides) and Ffh, a $48-\mathrm{kDa}$ protein. Ffh is a GTPase that consists of three

Reprint requests to: Wolfgang Wintermeyer, Institute of Molecular Biology, University of Witten/Herdecke, Stockumer Str. 10, 58448 Witten, Germany; e-mail: winterme@uni-wh.de; fax: 49-2302-926-117.

Abbreviations: Alx, Alexa Fluor; Bpy, BODIPY Fl; FRET, fluorescence resonance energy transfer; $\mathrm{mBrB}$ and $\mathrm{dBrB}$, mono- and dibromobimane; OG, Oregon Green; RNC, ribosome nascent-chain complex; SRP, signal recognition particle.

Article and publication are at http://www.rnajournal.org/cgi/doi/ 10.1261/rna.7242305. domains, the N-terminal $\mathrm{N}$ domain, the $\mathrm{G}$ domain, comprising the GTP binding site, and the C-terminal $\mathrm{M}$ domain where the RNA-binding site is located (Bernstein et al. 1989; Poritz et al. 1990). The $\mathrm{N}$ domain packs against the $G$ domain to form a contiguous unit called the NG domain. The bacterial SRP receptor is FtsY, a membrane-associated $52-\mathrm{kDa}$ protein that has an acidic N-terminal A domain followed by an NG domain (Gill and Salmond 1990). The NG domains of Ffh and FtsY are homologous in sequence, and the crystal structures of the NG domains of Ffh from Thermus aquaticus and of FtsY from E. coli revealed a high degree of structural similarity (Freymann et al. 1997; Montoya et al. 1997). Complex formation between $\mathrm{Ffh}$ and FtsY involves the symmetric association of their $\mathrm{G}$ domains, as shown by the recent crystal structures of the complex of the two NG domains (Egea et al. 2004; Focia et al. 2004).

The structure of the SRP is not known. Two crystal structures of free Ffh are available (Keenan et al. 1998; Rosendal et al. 2003). In the crystal structure of Ffh from T. aquaticus, there were three molecules of Ffh in the asymmetric unit, and the linkers between $\mathrm{G}$ and $\mathrm{M}$ domains were disordered (Keenan et al. 1998). Based on that crystal structure, there are three possible arrangements of $\mathrm{NG}$ and $\mathrm{M}$ domains, two of which (A/A, i.e., A chain for both NG and M domains; or 
B/A, B chain for NG and A chain for $\mathrm{M}$ ) are compatible with the length of the linker. In both arrangements, the NG and $\mathrm{M}$ domains are found sufficiently close to each other to make intramolecular contacts. In a recent crystal structure of the homologous SRP54 from Sulfolobus solfataricus alone and in complex with domain IV of SRP RNA, determined at a resolution of $4 \AA$, the linker could be traced, and the protein was present in a conformation in which the NG domain was detached from the $\mathrm{M}$ domain and which appeared to be stabilized by a hydrophobic interaction between $\mathrm{N}$ and M domains (Rosendal et al. 2003).

The binding site of Ffh on 4.5S RNA was mapped by genetic analysis (Wood et al. 1992), as well as by chemical and enzymatic footprinting (Lentzen et al. 1996). The RNA-binding site of $\mathrm{Ffh}$ was localized within the M domain (Römisch et al. 1989), and the crystal structure of the complex of the RNA-binding fragment of the $\mathrm{M}$ domain of $E$. coli $\mathrm{Ffh}$ with a 49-nt fragment of $4.5 \mathrm{~S}$ RNA comprising domain IV was determined (Batey et al. 2000). The crystal structure revealed contacts between the $\mathrm{M}$ domain and 4.5S RNA that explained the footprints of Ffh in internal loops A and B of 4.5S RNA. Internal loops C and $\mathrm{D}$ and stem $\mathrm{d}$ of $4.5 \mathrm{~S}$ RNA, where Ffh footprints were observed as well, were not included in the core structure (Batey et al. 2000), suggesting that those footprints (Lentzen et al. 1996) were due to protection by the NG domain or conformational changes in 4.5S RNA upon binding of the $\mathrm{M}$ domain. In the cryo-EM structure of the eukaryotic SRP homolog, the contact between the NG and $\mathrm{M}$ domains is limited to a potential connection trough the flexible loop of the $\mathrm{M}$ domain to the NG interface, and there is no contact between the NG domain and 4.5S RNA (Halic et al. 2004), and the domain arrangement of Ffh is different from either crystal structure (Keenan et al. 1998; Rosendal et al. 2003).

The structure of a complex of the NG domains of Ffh and FtsY revealed a symmetric heterodimer featuring a composite active site that contains two molecules of GDPNP (Egea et al. 2004; Focia et al. 2004). The arrangement of the two NG domains in the structure imposed constrains on the possible positions of the $\mathrm{M}$ domain of Ffh. Probing the structure of the Ffh-FtsY complex by cross-linking and mass spectroscopy (Chu et al. 2004) suggested that the solution structure of the Ffh-FtsY complex is in good agreement with the crystal structure (Egea et al. 2004; Focia et al. 2004) and that the M domain is positioned in close proximity to the Ffh-FtsY interface in the complex. Furthermore, the cross-linking studies suggested that in the Ffh-FtsY complex the $\mathrm{M}$ domain assumes a position different from that suggested by $\mathrm{Ffh}$ crystal structures (Keenan et al. 1998; Rosendal et al. 2003).

The aim of the present work was to clarify whether the NG domain interacts with the M domain or 4.5S RNA in free Ffh, SRP, and in the complex with FtsY. The arrangement of NG and M domains was studied by cross-linking and fluorescence resonance energy transfer (FRET) techniques. The binding of the NG domain to 4.5S RNA and the conformational rearrangements taking place upon SRP formation were monitored by chemical footprinting and fluorescence measurements. Finally, the interaction between Ffh and FtsY was studied by fluorescence using a variant of Ffh in which the relative mobility of NG and $\mathrm{M}$ domains was restricted by a cross-link.

\section{RESULTS}

\section{Complex formation between isolated NG and $M$ domains of $F f h$}

The interaction between the domains of Ffh was examined using the isolated NG domain (residues $1-295 ; 33 \mathrm{kDa}$ ) and M domain (positions 297-453; $17 \mathrm{kDa}$ ), monitoring fluorescence resonance energy transfer (FRET) between fluorophores attached to a single cysteine residue in either domain. BODIPY FL (Bpy) at position 406 of the $\mathrm{M}$ domain was used as donor [Ffh-M(Bpy406)] and Alexa 546 (Alx) at position 84 of the NG domain as acceptor [Ffh-NG(Alx84)]. FRET was monitored by the decrease of the fluorescence lifetime of Bpy (Table 1). With Ffh-M(Bpy406) alone, the lifetime was $5.2 \mathrm{nsec}$, and the lifetime decreased to 4.7 nsec upon addition of unlabeled NG domain. When Ffh-NG(Alx84) was added, the lifetime of Ffh-M(Bpy406) dropped to $0.90 \mathrm{nsec}$, indicating FRET at an efficiency of $81 \%$ (Fig. 1B; Table 1). Analogous results were obtained by monitoring the steady-state fluorescence emission of Ffh-M(Bpy406): the emission decreased to $74 \%$ upon addition of unlabeled NG domain and to $21 \%$ when the Alx-labeled NG domain was added, yielding a FRET efficiency of $72 \%$ (Table 1). Distances between donor and acceptor of $38 \pm 6 \AA$ and $41 \pm 8 \AA$, respectively, were calculated from the changes in the lifetime and fluorescence intensity of the Bpy donor, comparing the values measured in the presence of unlabeled and acceptor-labeled NG domain (Materials and Methods). The indicated distance ranges take into account the uncertainty about the orientation of the fluorophores, as assessed by depolarization measurements

\begin{tabular}{|c|c|c|c|}
\hline Ligand & Ligand & $\begin{array}{c}\text { Lifetime }^{\mathrm{a}} \\
\quad \text { (nsec) }\end{array}$ & Rel. fluorescence ${ }^{b}$ \\
\hline Ffh-M(Bpy406) & - & 5.2 & 1.0 \\
\hline " & Ffh-NG & 4.7 & 0.74 \\
\hline$"$ & Ffh-NG(Alx84) & $0.9^{c}$ & 0.21 \\
\hline
\end{tabular}


A

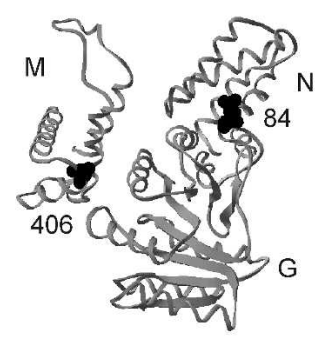

B

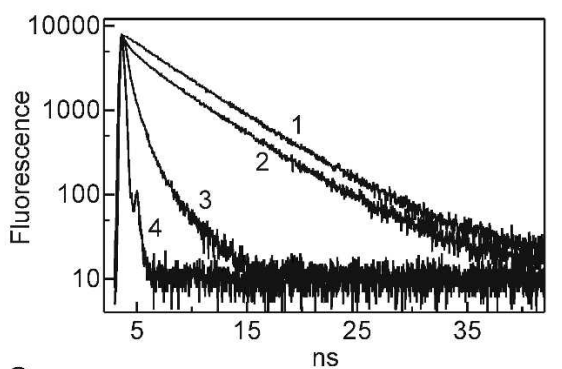

C

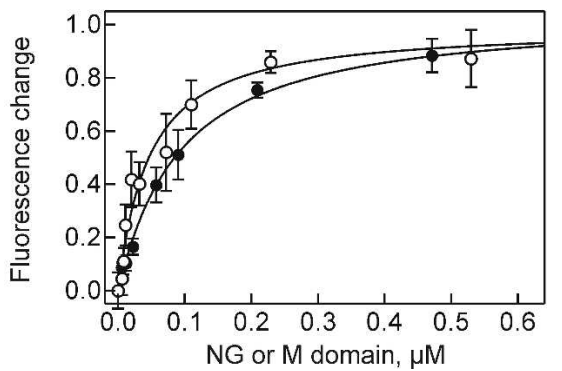

FIGURE 1. Interaction of isolated $\mathrm{NG}$ and $\mathrm{M}$ domains monitored by fluorescence. (A) Positions of fluorescence labels. NG and M domains are shown in the A/A arrangement (Keenan et al. 1998); cysteine residues that were used for attaching fluorescence labels are indicated. (B) FRET measurements. Fluorescence decay curves were measured for Ffh-M(Bpy406) (fluorescence donor) alone (1), in the presence of unlabeled NG domain (2), or in the presence of Ffh-NG(Alx84) (acceptor) (3); the time response curve of the excitation pulse is also indicated (4). Fluorescence lifetimes derived from the decay curves are summarized in Table 1. (C) Fluorescence titrations. The fluorescence emission of Ffh-NG(OG84) upon addition of unlabeled Ffh-M (O) or of Ffh-M(Bpy406) upon addition of unlabeled Ffh-NG $(\bullet)$ was monitored. The amplitudes of the fluorescence changes $(11 \%$ increase and 26\% decrease for OG84 and Bpy406, respectively) were set to 1.0 .

(Materials and Methods), and the standard deviations of the lifetime and fluorescence measurements (Table 1). Within these ranges, the results of the lifetime and steady-state fluorescence measurements coincide. About the same distance was derived from FRET measurements in native Ffh (I. Buskiewicz, unpubl.), supporting the view that the arrangement of NG and $\mathrm{M}$ domains in the complex of the isolated domains and in full-length Ffh is the same.

The binding affinity between NG and M domains was determined by equilibrium titration, monitoring the fluorescence change of Ffh-M(Bpy406) caused by binding of the unlabeled NG domain or of Ffh-NG(Alx84) by binding of the unlabeled $\mathrm{M}$ domain (Fig. 1C). Similar $\mathrm{K}_{\mathrm{d}}$ values of $90 \pm 20$ and $40 \pm 10 \mathrm{nM}$, respectively, were obtained by the two measurements. For calculation of the free binding energy, we used an average $K_{d}$ value of $60 \pm 30 \mathrm{nM}$, corresponding to a free binding energy of $\Delta \mathrm{G}^{\circ}=-9.8 \mathrm{kcal} / \mathrm{mol}$ (Table 2).

\section{Binding of the isolated NG domain of Ffh to 4.5S RNA}

Binding of full-length Ffh protein $(48 \mathrm{kDa})$ to $4.5 \mathrm{~S}$ RNA (114 nt; $35 \mathrm{kDa}$ ) can be studied by band shift in nondenaturing gel electrophoresis (Lentzen et al. 1994; Kusters et al. 1995; Jagath et al. 2001). Under the same conditions, the isolated NG domain of Ffh $(33 \mathrm{kDa})$ did not cause a significant shift of 4.5S RNA (data not shown), suggesting that the complex-if formed - was of low stability. However, using gel filtration on Superdex 75, a complex of 4.5S RNA and the NG domain, both present at $5 \mu \mathrm{M}$ concentration, could be detected (Fig. 2, trace 1$)$. At lower concentrations of protein $(0.5 \mu \mathrm{M})$ and RNA $(0.1 \mu \mathrm{M})$, part of the RNA remained unbound (trace 2$)$, indicating a $\mathrm{K}_{\mathrm{d}}$ of the complex of $\sim 0.5 \mu \mathrm{M}$.

\section{Chemical footprinting reveals separate binding sites for $M$ and NG domains on 4.5S RNA}

According to previous chemical footprinting results, the binding site of Ffh on 4.5S RNA extends from internal loop A through internal loop $\mathrm{C}$ and the adjacent stem (Fig. 3A). The M-domain footprints in internal loops $\mathrm{A}$ and B (DMS modification; Fig. 3B) are consistent with the contacts revealed by the crystal structure of the complex of an M-domain fragment of Ffh and a 49 mer construct of $4.5 \mathrm{~S}$ RNA comprising loops $\mathrm{A}$ and B (Batey et al. 2000, 2001). Using kethoxal modification, a strong footprint at position G27 was observed for both full-length Ffh, as described earlier (Lentzen et al. 1996), and the isolated NG domain (Fig. 3C). The isolated $\mathrm{M}$ domain caused no protection in that region of $4.5 \mathrm{~S}$ RNA. These results suggest that the NG domain binds to

TABLE 2. Summary of binding affinities

\begin{tabular}{llcc}
\hline Ligand & \multicolumn{1}{c}{ Ligand } & $\mathrm{K}_{\mathrm{d}}(\mathrm{M})$ & $\Delta \mathrm{G}^{\circ}(\mathrm{kcal} / \mathrm{mol})$ \\
\hline Ffh-NG & Ffh-M & $(6.0 \pm 0.3) \times 10^{-8}$ & $-9.8 \pm 0.5$ \\
Ffh & $4.5 S \mathrm{RNA}$ & $(5.2 \pm 0.5) \times 10^{-11}$ & $-14.0 \pm 1.3$ \\
" & $61 \mathrm{mer}$ & $(3.3 \pm 0.3) \times 10^{-11}$ & $-14.3 \pm 1.3$ \\
Ffh-M & $4.5 \mathrm{~S}$ RNA & $(3.3 \pm 0.2) \times 10^{-11}$ & $-14.3 \pm 0.9$ \\
" & $61 \mathrm{mer}$ & $(2.8 \pm 0.3) \times 10^{-11}$ & $-14.4 \pm 1.5$ \\
Ffh-NG & $4.5 \mathrm{~S}$ RNA & $(5.6 \pm 1.2) \times 10^{-7}$ & $-8.5 \pm 1.8$ \\
" & $61 \mathrm{mer}$ & $(6.2 \pm 0.9) \times 10^{-7}$ & $-8.4 \pm 1.2$ \\
" & $49 \mathrm{mer}$ & $(2.0 \pm 0.5) \times 10^{-5}$ & $-6.4 \pm 1.6$ \\
\hline
\end{tabular}




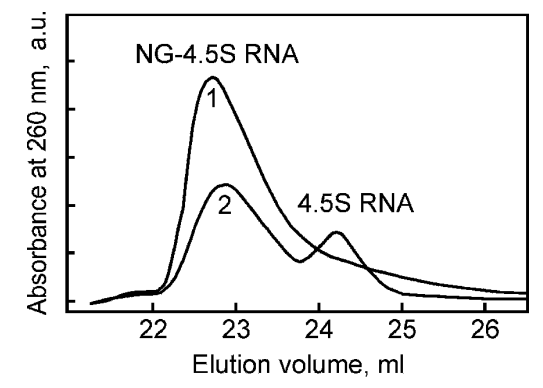

FIGURE 2. Complex formation between the NG domain of Ffh and 4.5S RNA. The isolated NG domain (Materials and Methods) and 4.5S RNA were mixed in $100 \mu \mathrm{L}$ of buffer A at $5 \mu \mathrm{M}$ concentration each (1) or $0.5 \mu \mathrm{M}$ and $0.1 \mu \mathrm{M}$ (2), respectively, and separated on a Superdex 75 gel filtration column in buffer A at $25^{\circ} \mathrm{C}$. Absorbance at $260 \mathrm{~nm}$ is plotted in arbitrary units.

4.5S RNA in the region of internal loop $\mathrm{C}$ and the adjacent stem; alternatively, the change of the reactivity against kethoxal could be caused indirectly by changing the conformation at this region. Thus, the footprint of full-length Ffh appears to be composed of the footprints of the $\mathrm{M}$ and NG domains, indicating that in the complex of $4.5 \mathrm{~S}$ RNA with full-length Ffh, both $\mathrm{M}$ domain and NG domain are bound to the RNA.

\section{Affinities of Ffh, $M$ domain, and NG domain for 4.5S RNA}

The binding affinities of Ffh and the isolated $\mathrm{M}$ and NG domains to $4.5 \mathrm{~S}$ RNA were determined by titration experiments. In addition to full-length 4.5S RNA, two fragments of 4.5S RNA were used, a 61mer (nt 21-81), comprising internal loops A through $\mathrm{C}$, and a 49 mer that comprised internal loops $\mathrm{A}$ and $\mathrm{B}$ and was closed by an extended double-stranded stem replacing loop C (Batey et al. 2000). $5^{\prime}-{ }^{32} \mathrm{P}$-labeled RNAs were used at 5 pM concentration, and RNA-protein complexes were isolated by nitrocellulose filtration. Titration of 4.5S RNA with full-length Ffh yielded a $K_{d}$ of $52 \mathrm{pM}$ (Fig. 4A), close to the value previously obtained at similar buffer conditions (Batey et al. 2001; Batey and Doudna 2002). At different buffer conditions and in the presence of detergent, we previously obtained significantly weaker binding (Jagath et al. 2001). A similar $K_{d}$ value of $33 \mathrm{pM}$ was obtained for Ffh binding to the 61 mer fragment of $4.5 \mathrm{~S}$ RNA (Table 2). The isolated M domain exhibited the same affinity, $\sim 30 \mathrm{pM}$, of binding to 4.5S RNA (Fig. 4A) and the 61mer (Table 2). The titration of 4.5S RNA with the isolated NG domain of Ffh yielded a much higher $K_{d}$ value of $0.7 \mu \mathrm{M}$ (Fig. $4 \mathrm{~B}$ ); the yield of complex was reduced to $60 \%$, indicating some dissociation of the complex during isolation. No complex between the NG domain and

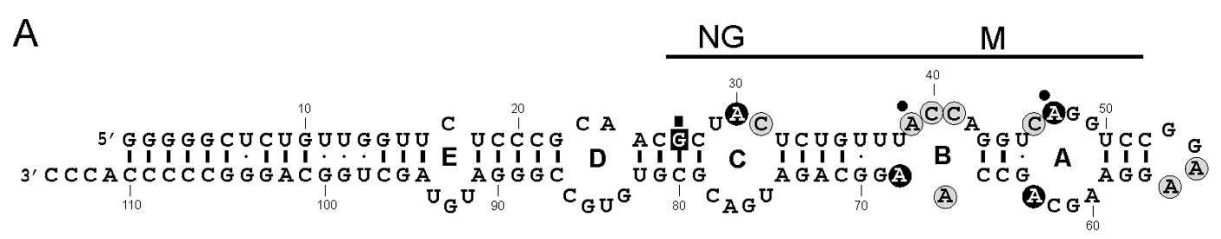

B

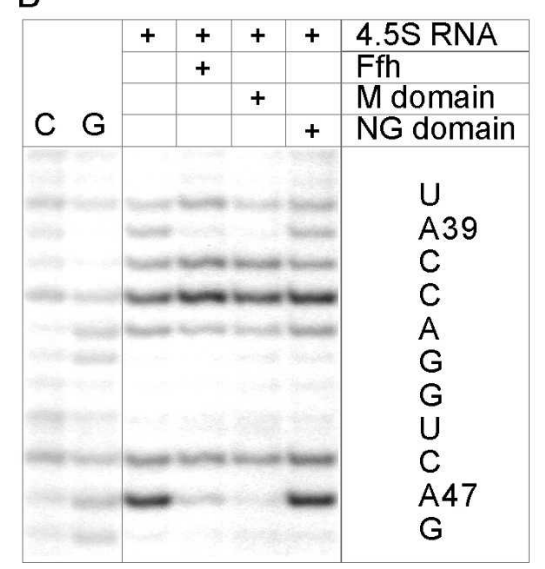

C

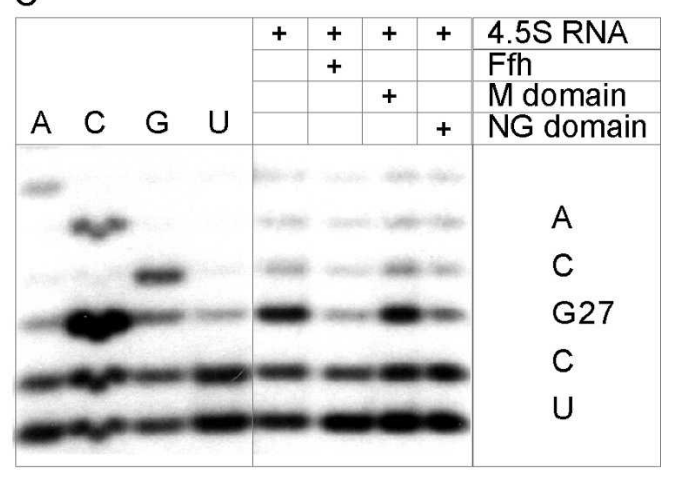

FIGURE 3. Footprinting of full-length Ffh, NG domain, and M domain on 4.5S RNA. (A) Predicted secondary structure of 4.5S RNA. Encircled nucleotides (A,C) were found reactive toward dimethyl sulfate, the boxed nucleotide $(G)$ toward kethoxal. Strong and weak reactivities are indicated in black and gray, respectively. Protection is indicated by small circles or a square. The binding site of Ffh, as derived from previous footprinting results (Lentzen et al. 1996), is delineated and the approximate binding sites of $\mathrm{M}$ and NG domains are indicated. (B) DMS modification. $C, G$, sequencing lanes. (C) Kethoxal modification. $A, C, G, T$, sequencing lanes. The positions of nucleotides protected from modification are indicated in the sequences to the right. 


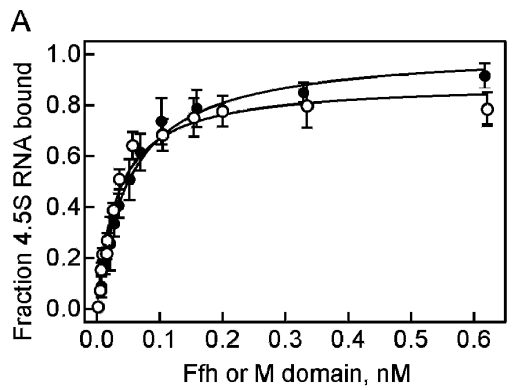

B

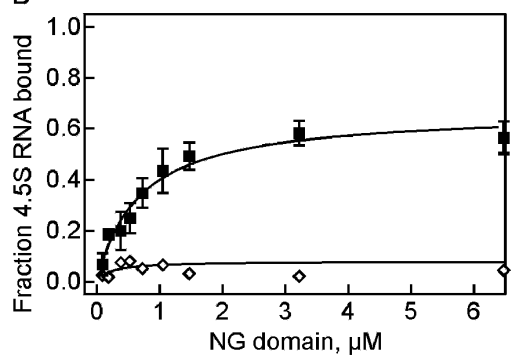

C

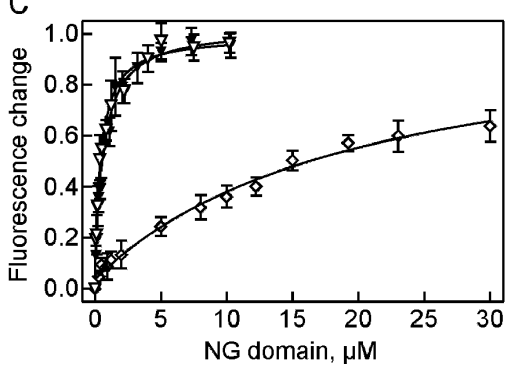

FIGURE 4. Quantitation of $\mathrm{Ffh}$ and $\mathrm{Ffh}$ domains binding to $4.5 \mathrm{~S}$ RNA. (A) Binding of Ffh and $\mathrm{M}$ domain. Binding was measured by nitrocellulose filtration with ${ }^{32} \mathrm{P}$-labeled 4.5S RNA $(5 \mathrm{pM})$. Ffh $(\bullet)$, $\mathrm{M}$ domain (O). (B) Binding of NG domain. ${ }^{32}$ P-labeled 4.5S RNA ( $)$ or 49 mer $(\diamond)$ were present at $80 \mathrm{nM}$ concentration. $(C)$ Fluorescence titrations with NG domain. 4.5S RNA $(\nabla), 61 \mathrm{mer}(\nabla)$, and $49 \mathrm{mer}$ $(\diamond)$ were labeled with Alexa 555 (Alx) at the $3^{\prime}$ end; titrations, monitoring the fluorescence emission of the Alx probe, were performed and evaluated as described in Materials and Methods. Standard deviations of individual points are indicated by error bars (three or more independent measurements). The respective fits are indicated by continuous lines; $\mathrm{K}_{\mathrm{d}}$ values obtained from the fits are summarized in Table 2.

the 49mer fragment of 4.5S RNA was observed by nitrocellulose filtration, suggesting that the complex did not form or was too unstable to be detected by filtration. Complex formation was specific, as the addition of tRNA or 5S rRNA in 100-fold excess had no influence on the titration (data not shown).

Binding of the NG domain to 4.5S RNA and 4.5S RNA fragments was also monitored by fluorescence titrations, i.e., at true equilibrium conditions. RNAs were labeled by introducing the fluorescent probe Alexa 555 at the $3^{\prime}$ end (Materials and Methods). Fluorescence titrations yielded $\mathrm{K}_{\mathrm{d}}$ values of about $0.6 \mu \mathrm{M}$ for NG binding to full-length $4.5 \mathrm{~S}$ RNA and the 61mer fragment (Fig. 4C), in keeping with the results from nitrocellulose filtration. Binding of the NG domain to the 49 mer fragment was very weak, $K_{d}=20$ $\mu \mathrm{M}$, indicating that the 49 mer fragment does not comprise the (complete) binding site of the NG domain. Practically no signal change was observed with an even shorter fragment of 39 nt comprising internal loops A and B closed by a short double helix (data not shown).

Binding of 4.5S RNA to the NG domain labeled at position 84 with Oregon Green (OG), Ffh-NG(OG84), increased the fluorescence by $15 \%$. Fluorescence titrations yielded $\mathrm{K}_{\mathrm{d}}$ values of $0.6 \pm 0.1 \mu \mathrm{M}$ for binding of $4.5 \mathrm{~S}$ RNA and the 61mer fragment to the labeled NG domain (Table 2).

\section{Cross-linking $G$ and $M$ domains of $F$ fh abrogates 4.5S RNA binding}

In order to verify whether NG and $\mathrm{M}$ domains of Ffh must come apart to allow complex formation with 4.5S RNA, we studied the effect of introducing a chemical cross-link between $\mathrm{G}$ and $\mathrm{M}$ domain. As a cross-linker, we used dibromobimane $(\mathrm{dBrB})$, which specifically reacts with thiol groups and can cross-link pairs of thiol groups within 3-6 $\AA$ of one another (Mornet et al. 1985). The cross-linking reaction can be monitored by fluorescence, because $\mathrm{dBrB}$ becomes fluorescent when the two bromine atoms, which are strong quenchers of fluorescence, are released during the reaction with thiol groups. Control reactions were performed with monobromobimane $(\mathrm{mBrB})$, which becomes fluorescent upon coupling to a single thiol group. Cysteine residues were engineered into two positions of Ffh, 231 and 377, that appeared sufficiently close in the A/A arrangement of $\mathrm{NG}$ and $\mathrm{M}$ domains in the crystal structure of T. aquaticus Ffh (Keenan et al. 1998) (Fig. 5A). The reaction of the double mutant Ffh(C231/377) with $\mathrm{dBrB}$ was measured after a 2-h incubation (Fig. 5B). Control reactions of the respective single mutants $\mathrm{Ffh}(\mathrm{C} 231)$ and $\mathrm{Ffh}(\mathrm{C} 377)$ with $\mathrm{mBrB}$ reached comparable fluorescence levels. This strongly indicates that the cross-linked cysteine residues, 231 and 377, were close to one another in the native form of the double mutant. Another double mutant, $\mathrm{Ffh}(\mathrm{C} 17 / 344)$, did not yield a fluorescent product with $\mathrm{dBrB}$, i.e., no cross-link, consistent with the large distance between those two cysteine residues in the tertiary structure of Ffh, independently of the configuration of domains. Mutant Ffh lacking any cysteine, Ffh(S406), did not react with $\mathrm{dBrB}$. Ffh $(\mathrm{C} 231 / 377)$ bound to $4.5 \mathrm{~S}$ RNA formed hardly any cross-linked product upon reaction with $\mathrm{dBrB}$. This indicates that in the complex, the two cysteine residues at positions 231 and 377 are too far apart to form the cross-link, suggesting a separation of $\mathrm{M}$ and $\mathrm{G}$ domains upon Ffh binding to 4.5S RNA. The electrophoretic mobility of bimane-cross-linked Ffh was the same as that of free Ffh (Fig. 5B, inset), which demonstrates that the cross-linked protein was monomeric, i.e., that the cross-link was strictly intramolecular.

The inhibition of $\mathrm{dBrB}$ cross-linking in the $\mathrm{Ffh}(\mathrm{C} 231 / 377)$ 4.5S RNA complex suggested that the arrangement of $M$ and NG domains was changed upon formation of SRP. 
A

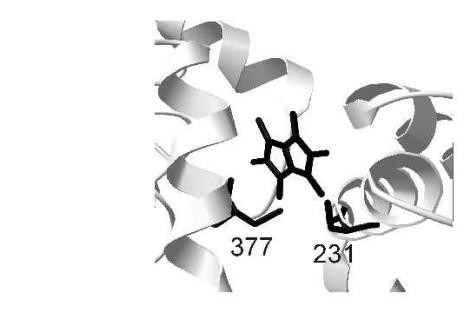

C

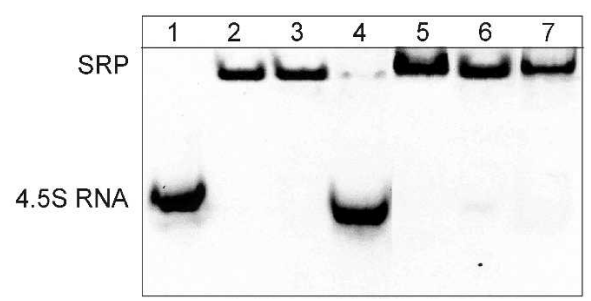

B

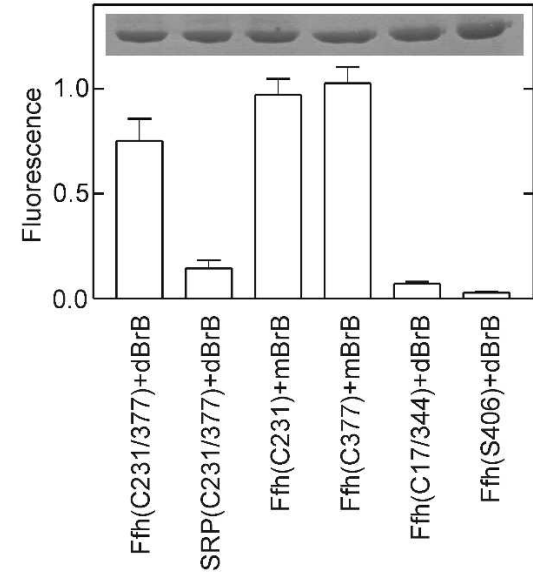

FIGURE 5. Bimane cross-linking of $\mathrm{G}$ and $\mathrm{M}$ domains of Ffh. $(A)$ Model of bimane crosslinked to $\mathrm{Ffh}(\mathrm{C} 231 / 377)$. The structure of T. aquaticus $\mathrm{Ffh}$ in the A/A orientation was used (Keenan et al. 1998) (PDF acc. no. 2FFH) in which residues 228 and 363, in E. coli Ffh corresponding to residues 231 and 377, respectively, were replaced with cysteines using RasMol software. $(B)$ Reaction of dibromobimane $(\mathrm{dBrB})$ and monobromobimane $(\mathrm{mBrB})$ with cysteine mutants of $\mathrm{Ffh}$ as monitored by bimane fluorescence after 120-min incubation. (Inset) SDS gel showing the amounts of Ffh protein in the samples. $(C)$ Ffh binding to 4.5S RNA. The formation of SRP was monitored by band shift in a $7 \%$ nondenaturing polyacrylamide gel; 4.5S RNA was stained with ethidium bromide. Lane 1, 4.5S RNA; 2, + Ffh; 3, + Ffh $(\mathrm{C} 231 / 377) ; 4$, + Ffh $(\mathrm{C} 231 / 377)$ cross-linked with $\mathrm{dBrB} ; 5$, Ffh $(\mathrm{C} 231)$ reacted with $\mathrm{mBrB} ; 6, \mathrm{Ffh}(\mathrm{C} 377)$ reacted with $\mathrm{mBrB} ; 7, \mathrm{Ffh}(\mathrm{C} 17 / 344)$ reacted with $\mathrm{dBrB}$.

Therefore, cross-linked Ffh was examined with respect to $4.5 \mathrm{~S}$ RNA binding, using the gel shift assay (Valent et al. 1995; Jagath et al. 2001) (Fig. 5C). According to this assay, bimanecross-linked Ffh was no longer able to bind 4.5S RNA, whereas Ffh modified with bimane at single positions was as active as unmodified $\mathrm{Ffh}$. This result strongly indicates that binding of Ffh to $4.5 \mathrm{~S}$ RNA requires a rearrangement of $\mathrm{M}$ and G domains.

\section{Cross-linking $\mathrm{G}$ and $\mathrm{M}$ domains of Ffh impairs FtsY binding}

Finally, we examined the interaction of bimane-crosslinked Ffh with the SRP receptor, FtsY, monitoring the fluorescence of a single tryptophan residue in mutant FtsY(Trp342) (Jagath et al. 2000). Binding of wild-type Ffh (data not shown) (Jagath et al. 2000) or mBrB-modified $\mathrm{Ffh}(\mathrm{C} 231 / 377)$ to FtsY caused a twofold fluorescence increase of $\operatorname{Trp} 342$ and a blue-shift of the emission spectrum by $\sim 10 \mathrm{~nm}$ (Fig. 6A). With bimane-cross-linked Ffh, the fluorescence increase of Trp342 was less, $\sim 50 \%$, and there was no spectral shift. Fluorescence titrations revealed an affinity of wild-type Ffh for FtsY of $\sim 60 \mathrm{nM}$ (Fig. 6B). The affinity was not affected by the attachment of bimane from $\mathrm{mBrB}$ to $\mathrm{Ffh}(\mathrm{C} 231 / 377)$, whereas cross-linking of
$\mathrm{Ffh}(\mathrm{C} 231 / 377)$ with $\mathrm{dBrB}$ diminished the affinity $\sim 20$-fold to $1.3 \mu \mathrm{M}$.

\section{DISCUSSION}

The domain arrangement of bacterial Ffh is not known, and the crystal and cryo-EM structures solved thus far show different relative orientations of NG and $\mathrm{M}$ domains (Keenan et al. 1998; Rosendal et al. 2003; Halic et al. 2004). The present data show that in free Ffh the NG domain binds to the $M$ domain with high affinity $(60 \mathrm{nM})$, implying an extended interaction area between the two domains. In the arrangements reported for S. sulfolobus Ffh (Rosendal et al. 2003) and for canine SRP54 on the ribosome (Halic et al. 2004), or in the B/Adomain arrangement in T. aquaticus Ffh (Keenan et al. 1998), the areas of interaction between NG and M domains are too small to account for the observed high affinity of the interaction. In contrast, in the A/A domain arrangement in the crystal structure of $\mathrm{Ffh}$ from T. aquaticus (Keenan et al. 1998), the M domain forms extensive contacts with both $\mathrm{N}$ and $\mathrm{G}$ domains, which would account for the observed affinity of the complex of NG and M domains. Furthermore, the observation that cysteine residues at positions 231 (G domain) and 377 (M domain) were readily cross-linked by dibromobimane strongly supports the $\mathrm{A} / \mathrm{A}$ arrangement, as the two residues are within cross-linking distance $(5 \AA)$ in the A/A configuration only, and far apart $(>50 \AA)$ in all other configurations (Keenan et al. 1998). Additional support for the A/A configuration of free Ffh comes from FRET measurements between fluorophores placed at various positions in the NG and M domains (I. Buskiewicz, unpubl.). Thus, bacterial Ffh in solution apparently is present in a compact conformation with NG and M domains tightly bound to one another. On the other hand, the domains appear to separate upon Ffh binding to 4.5S RNA (see below), and may separate further at some later stage in the SRP cycle.

The present results reveal that Ffh interacts with 4.5S RNA through both M and NG domains. While the $M$ domain-RNA interaction previously was characterized at atomic resolution (Batey et al. 2000), not much is known about the interaction of the NG domain. The results from chemical footprinting suggest that the interaction involves the region around G27 of 4.5S RNA (present paper), explaining the part of the Ffh footprint that extends beyond the footprint due to binding of the $\mathrm{M}$ domain (Lentzen et al. 1996). Modeling 4.5S RNA into the crystal structure 
A

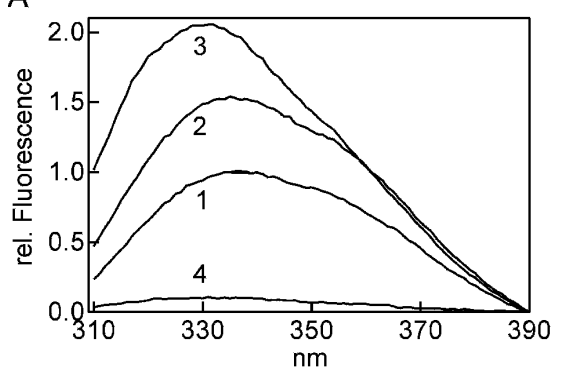

B

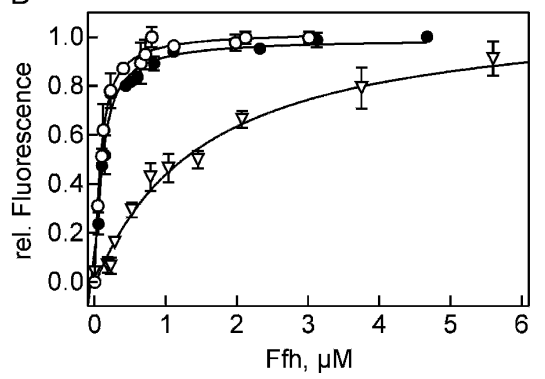

FIGURE 6. Inhibition of FtsY binding to Ffh by bimane cross-linking. (A) Fluorescence emission spectra of FtsY(Trp342). 1, FtsY(Trp342), $0.5 \mu \mathrm{M} ; 2$, $+\mathrm{Ffh}(\mathrm{C} 231 / 377)$ cross-linked with $\mathrm{dBrB}, 6 \mu \mathrm{M} ; 3$, $+\mathrm{Ffh}(\mathrm{C} 231 / 377)$ reacted with $\mathrm{mBrB}, 3 \mu \mathrm{M}$. 4, $\mathrm{Ffh}(\mathrm{C} 231 / 377)$ crosslinked with $\mathrm{dBrB}$ in the absence of FtsY. (B) Fluorescence titrations. Increasing amounts of $\mathrm{Ffh}(\mathrm{O}), \mathrm{Ffh}(\mathrm{C} 231 / 377)$ reacted with $\mathrm{mBrB}(\bullet)$, or $\mathrm{Ffh}(\mathrm{C} 231 / 377)$ cross-linked with $\mathrm{dBrB}(\nabla)$ were added to FtsY(Trp342) $(0.01 \mu \mathrm{M})$.

of free Ffh in the A/A configuration on the basis of the $\mathrm{M}$ domain-RNA crystal structure (Batey et al. 2000) indicates extensive steric clashes between the RNA and the NG domain. In order to avoid clashes and keep the NG domain in binding distance to the RNA, the NG and $\mathrm{M}$ domains have to be separated by a moderate movement of NG away from the $\mathrm{M}$ domain. In keeping with such a movement, Ffh in which the A/A configuration of $G$ and $\mathrm{M}$ domains was fixed by introducing a bimane cross-link was no longer active in binding to $4.5 \mathrm{~S}$ RNA, and, conversely, in Ffh bound to 4.5S RNA the cross-link was no longer formed. The conformation of Ffh in the complex with $4.5 \mathrm{~S}$ RNA is not known. It is not excluded that it assumes the unfolded conformation observed for archaeal SRP54 and its complex with domain IV RNA (Rosendal et al. 2003), although results from FRET measurements appear to indicate a different conformation (I. Buskiewicz, unpubl.).

The isolated NG domain of Ffh binds to 4.5S RNA with a free energy of binding of $\sim 8.5 \mathrm{kcal} / \mathrm{mol}$ (Table 2 ). The affinity of the isolated $M$ domain is much higher, $14.3 \mathrm{kcal} / \mathrm{mol}$. Were the RNA-binding affinities of the isolated domains simply additive, full-length $\mathrm{Ffh}$ would be expected to bind with a $\mathrm{K}_{\mathrm{d}}$ close to $10^{-18} \mathrm{M}$. However, it binds with a $\mathrm{K}_{\mathrm{d}}$ of $\sim 50 \mathrm{pM}\left(5 \times 10^{-11} \mathrm{M}\right)$, comparable to that of the $\mathrm{M}$ domain alone, indicating that part of the total binding energy, roughly equivalent to the free energy of
NG domain binding, is consumed by a conformational change required for complex formation. The observation that cross-linking the $M$ and $G$ domains, i.e., fixing them in the A/A conformation, abrogates $4.5 \mathrm{~S}$ RNA binding indicates that Ffh must change its conformation in order to accommodate the RNA. In fact, FRET measurements show that $\mathrm{M}$ and $\mathrm{NG}$ domains come apart upon binding the RNA by widening the cleft between $M$ and $G$ domain (I. Buskiewicz, unpubl.). The isolated domains bind strongly to one another, the binding energy amounting to $9.8 \mathrm{kcal} / \mathrm{mol}$ (Table 2). This value is close to the free-energy difference between full-length Ffh and the isolated NG and $\mathrm{M}$ domains. Assuming that in intact Ffh the two domains interact in the same way, this indicates that the major part of the conformational work during complex formation consists in the separation of the domains, although additional, less energy-consuming rearrangements are possible. In fact, fluorescence and chemical footprinting data indicate that Ffh binding induces a global conformational change in the RNA (Lentzen et al. 1994, 1996).

Cross-linking the $\mathrm{G}$ and $\mathrm{M}$ domains of Ffh also impaired complex formation with the SRP receptor, FtsY, lowering the binding affinity 20-fold. This can be explained on the basis of the crystal structures of free Ffh in the A/A configuration and of the complex of the NG domains of both Ffh and FtsY (Keenan et al. 1998; Egea et al. 2004; Focia et al. 2004). When the two structures are aligned on the $\mathrm{G}$ domain of Ffh, the M domain of Ffh and the NG domain of FtsY to a large part occupy the same space. Thus, in order to allow Ffh-FtsY complex formation, $M$ and NG domains of Ffh must move away from each other, and the cross-link apparently interferes with that movement. Interestingly, the binding of 4.5S RNA to Ffh greatly accelerates complex formation with FtsY (Peluso et al. 2000). The present results suggest that the acceleration is due to the domain rearrangement in Ffh that is induced by binding of $4.5 \mathrm{~S}$ RNA and makes the interaction interface on the NG domain of Ffh more easily accessible for FtsY. FtsY binding to SRP is impaired by base changes in the tetraloop and the adjacent stem of $4.5 \mathrm{~S}$ RNA (Jagath et al. 2001), indicating that a conformational change of the RNA is involved in ternary complex formation as well.

In conclusion, the present results show that conformational changes of $\mathrm{Ffh}$, notably a change of the arrangement of NG and M domains, are necessary for the binding of Ffh to 4.5S RNA to form SRP and for the binding of Ffh to the SRP receptor, FtsY. One may speculate that the modulation of these changes, e.g., by SRP binding to ribosomes displaying a signal sequence at the peptide exit, contributes to the interplay between SRP, FtsY, and trigger factor on the ribosome (Buskiewicz et al. 2004) and, thereby, to the timing of events during ribosome targeting to the membrane. Studying the dynamics of the interactions between translating ribosomes, SRP, and the SRP receptor will be one major objective of research in the future. 


\section{MATERIALS AND METHODS}

\section{Buffers and materials}

Buffer A: $25 \mathrm{mM}$ HEPES ( $\mathrm{pH} 7.5$ ), $70 \mathrm{mM}$ ammonium acetate, $30 \mathrm{mM}$ potassium acetate, $7 \mathrm{mM}$ magnesium acetate. Alexa Fluor 546 maleimide, Alexa Fluor 555 maleimide and hydrazide, Oregon Green 488 maleimide, BODIPY-Fl iodoacetamide, and mono- and dibromobimane were from Molecular Probes. Ni-NTA agarose was from QIAGEN. All other chemicals were obtained from Sigma or Merck.

\section{Preparation of 4.5S RNA}

Full-size 4.5S RNA and 61mer was prepared by T7 RNA polymerase transcription. The respective templates were amplified by Pfu polymerase using two primers, one coding for the region of the T7-RNA polymerase promoter and a second coding for the end of the RNA, and used in transcription reaction without further purification. In vitro transcription was carried out in $5 \mathrm{~mL}$ of $40 \mathrm{mM}$ Tris- $\mathrm{HCl}$ ( $\mathrm{pH} 7.5), 1 \mathrm{mM}$ spermidine, $10 \mathrm{mM}$ DTT, $0.05 \%$ Tween-20, $8 \mathrm{mM} \mathrm{MgCl}_{2}$ containing $1 \mathrm{mM}$ GMP, $2 \mathrm{mM}$ of ATP, GTP, CTP, and UTP each, $5 \mu \mathrm{g} / \mathrm{mL}$ of amplified DNA template, 1600 units/mL of T7 RNA polymerase (Fermentas), and $500 \mathrm{U} / \mathrm{mL}$ of RNase inhibitor (Fermentas) for $4 \mathrm{~h}$ at $37^{\circ} \mathrm{C}$. RNA was purified by ion exchange chromatography on MonoQ using a linear gradient of $0-1 \mathrm{M} \mathrm{LiCl}$ in $10 \mathrm{mM}$ Bis-Tris ( $\mathrm{pH}$ 6.0), $10 \mathrm{mM} \mathrm{MgCl}_{2}, 1 \mathrm{mM}$ EDTA. The 49-nt fragment of $4.5 \mathrm{~S}$ RNA comprising nt $32-74$ of $4.5 \mathrm{~S}$ RNA and additional three base pairs at the ends of the molecule (Batey et al. 2000) was purchased from Dharmacon.

\section{Plasmid construction, protein expression, and purification}

The constructs coding for the NG (residues 1-295) or M (residues 297-453 or 357-453) domains of Ffh were prepared by PCR mutagenesis and cloned into pET-16 and pET-24 (Novagen), respectively. The NG domain construct contained an N-terminal tag of 10 histidines and nine additional amino acids; the $\mathrm{M}$ domain constructs contained a C-terminal six-histidine tag. To control the functional activity of the recombinant domains, the NG and $\mathrm{M}$ domains were also prepared from full-length Ffh by V8 digestion (Zheng and Gierasch 1997) and tested for 4.5S RNA binding by fluorescence titrations similar to those shown in Figure 4. No differences in binding to $4.5 \mathrm{~S}$ RNA were found when recombinant domains and native domains produced by protease cleavage were compared (data not shown). The properties of the longer (residues 297-453) and shorter (residues 357-453) M domain constructs with respect to binding to $4.5 \mathrm{~S}$ RNA and NG domain were identical (data not shown).

To construct Ffh mutants with single and double cysteine substitutions, the single cysteine residue present at position 406 of native Ffh was substituted with serine. Ffh mutants with double cysteine replacements at positions $231 / 377$ or $17 / 344$, and single cysteine replacements at positions 84,231 , and 377 were generated by PCR mutagenesis by the QuickChange method using Pfu polymerase (Promega). Mutations were generated in plasmid pET24-Ffh coding for Ffh extended by six histidines at the $\mathrm{C}$ terminus. Muta- tions were confirmed by DNA sequencing. Introducing mutations and fluorescence dyes at the above positions did not affect the binding of Ffh to 4.5S RNA, FtsY, or ribosomes (data not shown).

Ffh mutants were expressed in E. coli BL21 (DE3) pLysS cells and purified on Ni-NTA agarose under nondenaturing conditions. Ten $g$ of cell pellet were resuspended in $40 \mathrm{~mL}$ of $20 \mathrm{mM}$ HEPES ( $\mathrm{pH} 7.5$ ), $300 \mathrm{mM} \mathrm{NaCl}, 0.1 \mathrm{mM}$ EDTA, $0.1 \mathrm{mM}$ Pefablock SC, and $10 \mathrm{mM}$ 2-mercaptoethanol, and the cells were opened by sonification (Branson Sonifier, duty cycle $50 \%$, output $4,3 \times$ for $5 \mathrm{~min}$ on ice). The extract was centrifuged at $20,000 \mathrm{~g}$ for $30 \mathrm{~min}$. The supernatant was incubated with $5 \mathrm{~mL}$ of Ni-NTA agarose equilibrated with $20 \mathrm{mM}$ HEPES (pH 7.5), $300 \mathrm{mM} \mathrm{KCl}$, and $10 \mathrm{mM} \mathrm{2-}$ mercaptoethanol on ice for $60 \mathrm{~min}$ under shaking. The resin was washed with $150 \mathrm{~mL}$ of $20 \mathrm{mM}$ HEPES (pH 7.5), $1 \mathrm{M} \mathrm{KCl}, 10 \mathrm{mM}$ imidazole, and $10 \mathrm{mM}$ 2-mercaptoethanol, and $\mathrm{Ffh}$ was eluted with $20 \mathrm{~mL}$ of $20 \mathrm{mM}$ HEPES (pH 7.5), $300 \mathrm{mM} \mathrm{KCl,} 250 \mathrm{mM}$ imidazole, and $20 \%$ glycerol. The proteins were further purified by gel filtration on a Superdex 75 column (Pharmacia) in buffer A with $10 \%$ glycerol. Proteins were concentrated by ultrafiltration using $30-\mathrm{kDa}$ (NG domain, full-size Ffh) or 5-kDa (M domain) membranes (Vivaspin) at $4^{\circ} \mathrm{C}$. The purity of proteins was $>95 \%$ according to SDS-PAGE. FtsY(Trp342) was expressed in E. coli BL21(DE3)pLysS cells and purified as described (Jagath et al. 2000).

\section{Fluorescence labeling}

Labeling of full-size Ffh and Ffh domains containing single cysteine residues with OG 488-maleimide, Alx 546-maleimide, or Bpy-iodoacetamide was carried out by incubating with a fivefold excess of dye over protein for $5 \mathrm{~h}$ on ice. Free dye was removed by gel filtration through Sephadex G-25.

For $3^{\prime}$-end labeling, 4.5S RNA (100 $\mathrm{A}_{260}$ units/mL) was oxidized by incubation in $0.1 \mathrm{M}$ sodium acetate $(\mathrm{pH} 5.3), 5 \mathrm{mM}$ $\mathrm{KIO}_{4}$ for $30 \mathrm{~min}$ at $0^{\circ} \mathrm{C}$ in the dark. The reaction was stopped by adding ethylene glycol to a concentration of $10 \mathrm{mM}$ and incubating further for $5 \mathrm{~min}$ at $0^{\circ} \mathrm{C}$. After ethanol precipitation, RNA was dissolved in $0.1 \mathrm{M}$ sodium acetate $(\mathrm{pH}$ 5.3), and reacted with a threefold excess of Alx 555 hydrazide for $5 \mathrm{~h}$ at $20^{\circ} \mathrm{C}$ in the dark. Free dye was removed by phenol extraction, RNA precipitated with ethanol, and finally dissolved in $20 \mathrm{mM}$ HEPES ( $\mathrm{pH} 7.5$ ), $7 \mathrm{mM}$ magnesium acetate, $0.5 \mathrm{mM}$ EDTA, and $100 \mathrm{mM} \mathrm{NH}_{4} \mathrm{Cl}$. The extent of labeling was $\sim 90 \%$, based on absorption measurements. Labeled 4.5S RNA was separated from unlabeled by FPLC on MonoQ using a gradient from 0.5 to $0.8 \mathrm{M} \mathrm{LiCl}$ in $20 \mathrm{mM}$ HEPES ( $\mathrm{pH} 7.5$ ), $7 \mathrm{mM}$ magnesium acetate, $0.5 \mathrm{mM}$ EDTA, and $100 \mathrm{mM} \mathrm{NH}_{4} \mathrm{Cl}$. Fractions containing 4.5S RNA were pooled, and the RNA was precipitated with ethanol.

\section{Dibromobimane cross-linking}

The homobifunctional cross-linker 4,6-bis(bromomethyl)-3,7dimethyl-1,5-diazabicyclo [3.3.0] octa-3,6-diene-2,8-dione (dibromobimane $(\mathrm{dBrB}))$ was used to introduce a cross-link between cysteines 231 and 377 in $\mathrm{Ffh}(\mathrm{C} 231 / 377)$. $\mathrm{dBrB}$ has two equivalent bromomethyl groups that can cross-link a thiol pair located within 3-6 $\AA$ of each other (Mornet et al. 1985). dBrB is nonfluorescent in solution but becomes fluorescent when both of its alkylating groups have reacted (Kosower and Kosower 1987; Ue 1987). 
Double mutants $\mathrm{Ffh}(\mathrm{C} 231 / 377)$ and $\mathrm{Ffh}(\mathrm{C} 17 / 344)$ were treated with a 1.1-fold molar excess of $\mathrm{dBrB}$. Samples were withdrawn over time, then purified from unbound cross-linker by gel filtration through Sephadex G-25, and bimane fluorescence was measured (excitation $390 \mathrm{~nm}$; emission $470 \mathrm{~nm}$ ). Single cysteine mutants $\mathrm{Ffh}(\mathrm{C} 231)$ or $\mathrm{Ffh}(\mathrm{C} 377)$ were labeled with a fivefold excess of $\mathrm{mBrB}$ and treated in the same way as the double mutant. Proteins were purified by FPLC on MonoQ using a gradient of 0.25-0.30 M KCl in $20 \mathrm{mM}$ HEPES ( $\mathrm{pH} 7.5$ ); fractions containing bimane-labeled proteins were identified by monitoring fluorescence as above. Samples were analyzed by SDS-PAGE.

\section{Gel shift and gel filtration assays}

SRP complex formation was monitored by nondenaturing 7\% PAGE (Jagath et al. 2001) in $50 \mathrm{mM}$ Tris-acetate ( $\mathrm{pH}$ 6.5), $75 \mathrm{mM}$ ammonium acetate, $10 \mathrm{mM}$ magnesium acetate, and $1 \mathrm{mM}$ EDTA at $4^{\circ} \mathrm{C}$. SRP was prepared by incubating Ffh $(2 \mu \mathrm{M})$ with $4.5 \mathrm{~S}$ RNA $(1 \mu \mathrm{M})$ in buffer $\mathrm{A}$ in the presence of $0.2 \mathrm{mM}$ GDPNP for $20 \mathrm{~min}$ at $20^{\circ} \mathrm{C}$ and loaded on the gel. GDPNP was present in the upper tank of the electrophoresis chamber as well; the running buffer was exchanged every $30 \mathrm{~min}$. Gels were stained with ethidium bromide and with Coomassie.

Complex formation between 4.5S RNA and the NG domain of Ffh was monitored by gel filtration on Superdex 75 (two tandem columns Pharmacia HR30; $1.6 \mathrm{~cm} \times 30 \mathrm{~cm}$ ). The samples were applied in $100 \mu \mathrm{L}$ and the column developed with $20 \mathrm{mM}$ HEPES (pH 7.5), $70 \mathrm{mM} \mathrm{NH}_{4} \mathrm{Cl}, 30 \mathrm{mM} \mathrm{KCl}, 7 \mathrm{mM} \mathrm{MgCl}_{2}$ at $0.5 \mathrm{~mL} /$ min. The position of RNA was monitored by absorbance at $260 \mathrm{~nm}$ in a flow-through monitor.

\section{Chemical probing}

To form the complex, $2 \mu \mathrm{M} 4.5 \mathrm{~S}$ RNA was incubated for $15 \mathrm{~min}$ at $25^{\circ} \mathrm{C}$ in buffer $\mathrm{A}$ in the presence of $6 \mu \mathrm{M}$ full-length Ffh, $6 \mu \mathrm{M}$ $\mathrm{M}$ domain, or $6 \mu \mathrm{M} \mathrm{NG}$ domain. Kethoxal modification of $4.5 \mathrm{~S}$ RNA complexes was performed in $50 \mu \mathrm{L}$ of buffer A containing $15 \mathrm{mg} / \mathrm{mL}$ kethoxal for $30 \mathrm{~min}$ at $25^{\circ} \mathrm{C}$. The reaction was stopped by the addition of $24 \mu \mathrm{L}$ of $250 \mathrm{mM}$ potassium borate, $150 \mathrm{mM}$ sodium acetate, $\mathrm{pH} 7.0$, and the complexes were precipitated with ethanol. DMS modification was carried out in $50 \mu \mathrm{L}$ of buffer A containing $0.5 \% \mathrm{DMS}$ for $10 \mathrm{~min}$ at $25^{\circ} \mathrm{C}$. The reaction was stopped by addition of $24 \mu \mathrm{L}$ of $1 \mathrm{M}$ Tris-HCl, pH 7.5, $1 \mathrm{M}$ 2-mercaptoethanol, $100 \mathrm{mM}$ EDTA. Pellets were dissolved in $200 \mu \mathrm{L}$ of $0.3 \mathrm{M}$ sodium acetate, $\mathrm{pH}$ 7.0, $0.5 \%$ SDS, 5 mM EDTA, and RNA was purified by phenol extraction and ethanol precipitation. Two oligodeoxynucleotide primers complementary to nt 94-105 and 39-52 of 4.5S RNA were used for primer extension that was carried out as described (Lentzen et al. 1996).

\section{Filter binding assay}

Ffh binding to 4.5S RNA and variants was measured by nitrocellulose filtration in buffer A containing $1 \mathrm{mM} \mathrm{DTT}, 0.1 \mathrm{mg} / \mathrm{mL}$ bovine serum albumin, and $0.1 \mathrm{mg} / \mathrm{mL}$ poly $(\mathrm{U}) .5^{\prime}{ }_{-}{ }^{32} \mathrm{P}$-labeled 4.5S RNA, $61 \mathrm{mer}$, or $49 \mathrm{mer}\left(5 \mathrm{pM} ; 1.6 \times 10^{9} \mathrm{dpm} / \mathrm{pmol}\right)$ were incubated with varying amounts of Ffh for $10 \mathrm{~min}$ at $25^{\circ} \mathrm{C}$. The mixtures were filtrated through nitrocellulose filters $(0.45 \mu \mathrm{m}$; Sartorius), filters were washed with $4 \mathrm{~mL}$ of reaction buffer, and bound RNA was determined by liquid scintillation counting.
Titration curves were evaluated by nonlinear fitting. At saturating protein concentrations, $85 \%-90 \%$ of RNA was found in complexes with full-length $\mathrm{Ffh}$ or the $\mathrm{M}$ domain; in the presence of saturating amounts of the NG domain, $\sim 60 \%$ of the RNA was recovered in the complex.

\section{Fluorescence titrations}

Steady-state fluorescence was measured in a PTI QuantaMaster C-61/ 2000 T-Format scanning spectrofluorometer. All titrations were carried out in buffer A containing 10\% (v/v) glycerol at $20^{\circ} \mathrm{C}$. Binding of the NG domain to $\mathrm{M}$ domain was monitored by fluorescence change of Ffh-NG(OG84) or Ffh-M(Bpy406). Initial concentrations of labeled $\mathrm{NG}$ or $\mathrm{M}$ domains were 0.013-0.06 $\mu \mathrm{M}$. Binding of 4.5S RNA and derivatives to the NG domain was monitored by the fluorescence change of Ffh-NG(OG84) or Alx 555 attached to the $3^{\prime}$ end of $4.5 \mathrm{~S}$ RNA (4.5S RNA(Alx114)). Excitation and emission wavelengths were 475 and $517 \mathrm{~nm}$ (OG) or 535 and $565 \mathrm{~nm}$ (Alx), respectively. The initial concentration of the Ffh-NG(OG84) was $0.052 \mu \mathrm{M}$ in $4.5 \mathrm{~S}$ RNA and $61 \mathrm{mer}$ titrations, and $0.49 \mu \mathrm{M}$ in the 49 mer titration. When Alx-labeled 4.5S RNA derivatives were used, the initial concentrations were $0.041 \mu \mathrm{M}$ (full-length $4.5 \mathrm{~S}$ RNA), 0.048 $\mu \mathrm{M}$ ( $61 \mathrm{mer}$ ), and $0.51 \mu \mathrm{M}$ (49mer). Binding of Ffh to FtsY was monitored by the fluorescence of the single Trp residue in FtsY(Trp342). After correction for dilution, the data were evaluated by nonlinear fitting to a quadratic equation describing ligand binding to one site using Table Curve software (Jandel Scientific).

\section{FRET measurements}

FRET was monitored by steady-state fluorescence or fluorescence lifetime measurements. Fluorescence of Bpy FL (excitation $490 \mathrm{~nm}$, emission $530 \mathrm{~nm}$ ) was measured on a PTI QuantaMaster C-61/ 2000 scanning spectrofluorometer. Time-domain lifetime measurements were carried out using a fluorescence lifetime spectrometer FluoTime 100 (PicoQuanT). Excitation pulses (440 nm, $10 \mathrm{MHz}$, 60 psec width) were generated by a laser diode system (PTD 800B with LDH PC 440, PicoQuanT). To exclude scattered light, a 500-nm liquid cut-off filter $\left(\mathrm{CrO}_{4}{ }^{2-} / \mathrm{Cr}_{2} \mathrm{O}_{7}{ }^{2-}, 0.3 \mathrm{M}\right.$, basic $\left.\mathrm{pH}\right)$ was used in the emission channel. Fluorescence decay measurements were carried out in buffer A containing $10 \%(\mathrm{v} / \mathrm{v})$ glycerol at room temperature.

Data analysis was performed using multiexponential fluorescence decay fitting software FluoFit v. 3.2.0 (PicoQuanT). For Ffh-M(Bpy406) alone or in the presence of unlabeled NG domain, single-exponential decay curves were obtained, yielding lifetimes of 5.2 and $4.7 \mathrm{nsec}$, respectively. In the presence of Ffh-NG(Alx84), a two-exponential decay curve with lifetimes of 1.38 and $0.46 \mathrm{nsec}$ and respective amplitudes of $48 \%$ and $52 \%$ was obtained, yielding an average lifetime of $0.9 \mathrm{nsec}$, which was used for calculating the FRET efficiency.

Distances between donor and acceptor, $R$, were estimated from FRET efficiencies, $E$, as calculated from the decrease of the fluorescence intensity or the lifetime of the donor according to the following equations (Lakowicz 1999):

$$
E=R_{0}^{6} /\left(R_{0}^{6}+R^{6}\right),
$$

where $R_{0}$ is the distance at which the FRET efficiency is $50 \%$; 


$$
\begin{gathered}
E=1-\left(\tau_{\mathrm{da}} / \tau_{\mathrm{d}}\right) \\
E=1-\left(\mathrm{F}_{\mathrm{da}} / \mathrm{F}_{\mathrm{d}}\right),
\end{gathered}
$$

where $\tau_{\mathrm{da}}, \mathrm{F}_{\mathrm{da}}$, and $\tau_{\mathrm{d}}, \mathrm{F}_{\mathrm{d}}$ are the lifetimes $(\tau)$ and fluorescence intensities $(\mathrm{F})$ of the donor measured in the presence and in the absence of acceptor, respectively. The value for $R_{0}$ was calculated using the equation:

$$
\mathrm{R}_{0}=\left(8.79 \times 10^{-25}\right)\left[n^{-4} Q \kappa^{2} J(\lambda)\right],
$$

where $n$ is the refractive index ( $n=1.4$ was used), $Q$ the quantum yield of the donor in the absence of acceptor, $\kappa^{2}$ the orientation factor, and $J(\lambda)$ the overlap integral between donor emission and acceptor absorption. Quantum yields were determined by comparing the integrated emission spectra of protein-bound dyes to that of a known standard as described (Lakowicz 1999); the quantum yield of Bpy FL attached to Ffh was 0.90. Distance ranges were calculated from the ranges of $\kappa^{2}$ values as determined from anisotropy measurements (Lakowicz et al. 1988):

$$
\begin{gathered}
\kappa_{\text {min }}^{2}=\frac{2}{3}\left[1-\left(d_{\mathrm{D}}^{x}+d_{\mathrm{A}}^{x}\right) / 2\right] ; \\
\kappa_{\max }^{2}=\frac{2}{3}\left[1+\left(d_{\mathrm{D}}^{x}+d_{\mathrm{A}}^{x}+3 d_{\mathrm{D}}^{x} d_{\mathrm{A}}^{x}\right) / 2\right],
\end{gathered}
$$

where $d_{i}^{x}=\left(r_{i} / r_{0}\right)^{1 / 2}$ are depolarization factors, and $r_{i}$ and $r_{0}$ are the measured limiting and fundamental anisotropies of donor (D) and acceptor (A), respectively.

$$
\begin{aligned}
& \mathrm{R}_{0 \min }=\left(3 \kappa_{\min }^{2} / 2\right)^{1 / 6} \times \mathrm{R}_{(2 / 3)} ; \\
& \mathrm{R}_{0 \max }=\left(3 \kappa_{\max }^{2} / 2\right)^{1 / 6} \times \mathrm{R}_{(2 / 3)},
\end{aligned}
$$

where $R_{(2 / 3)}$ is the distance calculated assuming $\kappa^{2}=2 / 3$. The calculated $R_{0}$ value was $48 \pm 2 \AA$ for Bpy FL and Alx 546 attached to protein.

\section{ACKNOWLEDGMENTS}

Time-resolved measurements were performed in the Center for Fluorescence Spectroscopy, University of Maryland at Baltimore, School of Medicine, MD, USA. We thank Ignacy Gryczynski for help with the time-resolved fluorescence measurements and discussions, and Carmen Schillings, Astrid Böhm, Simone Möbitz, and Petra Striebeck for expert technical assistance. The work was supported by the Deutsche Forschungsgemeinschaft, the Alfried Krupp von Bohlen und Halbach-Stiftung, and the Fonds der Chemischen Industrie.

Recieved November 18, 2004; accepted February 28, 2005.

\section{REFERENCES}

Batey, R.T. and Doudna, J.A. 2002. Structural and energetic analysis of metal ions essential to SRP signal recognition domain assembly. Biochemistry 41: 11703-11710.

Batey, R.T., Rambo, R.P., Lucast, L., Rha, B., and Doudna, J.A. 2000. Crystal structure of the ribonucleoprotein core of the signal recognition particle. Science 287: 1232-1239.

Batey, R.T., Sagar, M.B., and Doudna, J.A. 2001. Structural and energetic analysis of RNA recognition by a universally conserved protein from the signal recognition particle. J. Mol. Biol. 307: 229-246.
Bernstein, H.D., Poritz, M.A., Strub, K., Hoben, P.J., Brenner, S., and Walter, P. 1989. Model for signal sequence recognition from amino-acid sequence of $54 \mathrm{~K}$ subunit of signal recognition particle. Nature 340: 482-486.

Buskiewicz, I., Deuerling, E., Gu, S.Q., Jockel, J., Rodnina, M.V., Bukau, B., and Wintermeyer, W. 2004. Trigger factor binds to ribosome-signal-recognition particle (SRP) complexes and is excluded by binding of the SRP receptor. Proc. Natl. Acad. Sci. 101: 7902-7906.

Chu, F., Shan, S., Moustakas, D.T., Alber, F., Egea, P., Stroud, R.M., Walter, P., and Burlingame, A.L. 2004. Unraveling the interface of signal recognition particle and its receptor using chemical crosslinking and mass spectrometry. Proc. Natl. Acad. Sci. 101: 16454-16459.

Doudna, J.A. and Batey, R.T. 2004. Structural insights into the signal recognition particle. Annu. Rev. BioChem. 73: 539-557.

Egea, P.F., Shan, S.O., Napetschnig, J., Savage, D.F., Walter, P., and Stroud, R.M. 2004. Substrate twinning activates the signal recognition particle and its receptor. Nature 427: 215-221.

Focia, P.J., Shepotinovskaya, I.V., Seidler, J.A., and Freymann, D.M. 2004. Heterodimeric GTPase core of the SRP targeting complex. Science 303: 373-377.

Freymann, D.M., Keenan, R.J., Stroud, R.M., and Walter, P. 1997. Structure of the conserved GTPase domain of the signal recognition particle. Nature 385: 361-364.

Gill, D.R. and Salmond, G.P. 1990. The identification of the Escherichia coli ftsY gene product: An unusual protein. Mol. Microbiol. 4: $575-583$.

Halic, M., Becker, T., Pool, M.R., Spahn, C.M., Grassucci, R.A., Frank, J., and Beckmann, R. 2004. Structure of the signal recognition particle interacting with the elongation-arrested ribosome. Nature 427: 808-814.

Jagath, J.R., Rodnina, M.V., and Wintermeyer, W. 2000. Conformational changes in the bacterial SRP receptor FtsY upon binding of guanine nucleotides and SRP. J. Mol. Biol. 295: 745-753.

Jagath, J.R., Matassova, N.B., de Leeuw, E., Warnecke, J.M., Lentzen, G., Rodnina, M.V., Luirink, J., and Wintermeyer, W. 2001. Important role of the tetraloop region of $4.5 \mathrm{~S}$ RNA in SRP binding to its receptor FtsY. RNA 7: 293-301.

Keenan, R.J., Freymann, D.M., Walter, P., and Stroud, R.M. 1998. Crystal structure of the signal sequence binding subunit of the signal recognition particle. Cell 94: 181-191.

Keenan, R.J., Freymann, D.M., Stroud, R.M., and Walter, P. 2001. The signal recognition particle. Annu. Rev. BioChem. 70: 755-775.

Kosower, N.S. and Kosower, E.M. 1987. Thiol labeling with bromobimanes. Methods Enzymol. 143: 76-84.

Kusters, R., Lentzen, G., Eppens, E., van Geel, A., van der Weijden, C.C., Wintermeyer, W., and Luirink, J. 1995. The functioning of the SRP receptor FtsY in protein-targeting in E. coli is correlated with its ability to bind and hydrolyse GTP. FEBS Lett. 372: 253-258.

Lakowicz, J.R. 1999. Principles of fluorescence spectroscopy, pp. 305-309. Kluwer Academic, New York.

Lakowicz, J.R., Gryczynski, I., Cheung, H.C., Wang, C.K., Johnson, M.L., and Joshi, N. 1988. Distance distributions in proteins recovered by using frequency-domain fluorometry. Applications to troponin I and its complex with troponin C. Biochemistry 27: 9149-9160.

Lentzen, G., Dobberstein, B., and Wintermeyer, W. 1994. Formation of SRP-like particle induces a conformational change in E. coli 4.5S RNA. FEBS Lett. 348: 233-238.

Lentzen, G., Moine, H., Ehresmann, C., Ehresmann, B., and Wintermeyer, W. 1996. Structure of 4.5S RNA in the signal recognition particle of Escherichia coli as studied by enzymatic and chemical probing. RNA 2: 244-253.

Montoya, G., Svensson, C., Luirink, J., and Sinning, I. 1997. Crystal structure of the NG domain from the signal-recognition particle receptor FtsY. Nature 385: 365-368. 
Mornet, D., Ue, K., and Morales, M.F. 1985. Stabilization of a primary loop in myosin subfragment 1 with a fluorescent crosslinker. Proc. Natl. Acad. Sci. 82: 1658-1662.

Nagai, K., Oubridge, C., Kuglstatter, A., Menichelli, E., Isel, C., and Jovine, L. 2003. Structure, function and evolution of the signal recognition particle. EMBO J. 22: 3479-3485.

Peluso, P., Herschlag, D., Nock, S., Freymann, D.M., Johnson, A.E., and Walter, P. 2000. Role of 4.5S RNA in assembly of the bacterial signal recognition particle with its receptor. Science 288: 1640-1643.

Poritz, M.A., Bernstein, H.D., Strub, K., Zopf, D., Wilhelm, H., and Walter, P. 1990. An E. coli ribonucleoprotein containing 4.5S RNA resembles mammalian signal recognition particle. Science 250: 1111-1117.

Römisch, K., Webb, J., Herz, J., Prehn, S., Frank, R., Vingron, M., and Dobberstein, B. 1989. Homology of 54K protein of signal-recognition particle, docking protein and two E. coli proteins with putative GTPbinding domains. Nature 340: 478-482.
Rosendal, K.R., Wild, K., Montoya, G., and Sinning, I. 2003. Crystal structure of the complete core of archaeal signal recognition particle and implications for interdomain communication. Proc. Natl. Acad. Sci. 100: 14701-14706.

Ue, K. 1987. Intramolecular cross-linking of myosin subfragment 1 with bimane. Biochemistry 26: 1889-1894.

Valent, Q.A., Kendall, D.A., High, S., Kusters, R., Oudega, B., and Luirink, J. 1995. Early events in preprotein recognition in E. coli: interaction of SRP and trigger factor with nascent polypeptides. EMBO J. 14: 5494-5505.

Wood, H., Luirink, J., and Tollervey, D. 1992. Evolutionary conserved nucleotides within the E. coli 4.5S RNA are required for association with $\mathrm{P} 48$ in vitro and for optimal function in vivo. Nucleic Acids Res. 20: 5919-5925.

Zheng, N. and Gierasch, L.M. 1997. Domain interactions in E. coli SRP: Stabilization of M domain by RNA is required for effective signal sequence modulation of NG domain. Mol. Cell 1: 79-87. 

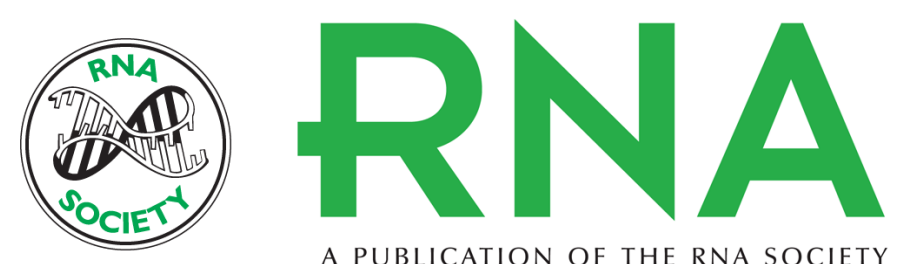

A PUBLICATION OF THE RNA SOCIETY

\section{Domain rearrangement of SRP protein Ffh upon binding 4.5S RNA and the SRP receptor FtsY}

IWONA BUSKIEWICZ, ANDRIY KUBARENKO, FRANK PESKE, et al.

RNA 2005 11: 947-957

References This article cites 32 articles, 10 of which can be accessed free at:

http://rnajournal.cshlp.org/content/11/6/947.full.html\#ref-list-1

\section{License}

Email Alerting Receive free email alerts when new articles cite this article - sign up in the box at the Service top right corner of the article or click here.

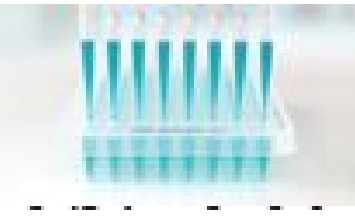

Providing Precise Solutions for your research.

To subscribe to RNA go to:

http://rnajournal.cshlp.org/subscriptions 